\title{
PENGEMBANGAN MULTIMEDIA PEMBELAJARAN UNTUK MENINGKATKAN KETERAMPILAN MENYIMAK BAHASA JERMAN
}

\author{
Fransiskus Dosi *, C. Asri Budiningsih \\ Universitas Negeri Yogyakarta. Jl. Colombo No. 1, Depok, Sleman 55281, Indonesia \\ * Corresponding Author. Email: cesargamof@gmail.com \\ Received: 28 July 2017; Revised: 9 May 2019; Accepted: 9 May 2019
}

\begin{abstract}
Abstrak
Penelitian ini bertujuan untuk: (1) menghasilkan multimedia pembelajaran keterampilan menyimak bahasa Jerman kelas X Materi Kennenlernen (Berkenalan), (2) mengetahui kebermanfaatan produk dalam meningkatkan keterampilan menyimak bahasa Jerman kelas X SMAN I Ngemplak. Penelitian pengembangan ini menggabungkan tiga model pengembangan yang diformulasikan oleh Borg \& Gall, Dick \& Carey, dan Allessi \& Trollip. Langkah-langkah pengembangan dibagi menjadi 4 fase, yaitu studi pendahuluan, pengembangan instruksional, pengembangan multimedia, dan evaluasi. Uji kelayakan melibatkan 2 ahli materi dan 2 ahli media pada uji alpha dan kemudian uji beta dilakukan oleh kelas X MIPA 2 yang berjumlah 28 peserta didik. Setelah uji beta dilanjutkan dengan tes sumatif yang melibatkan 32 peserta didik kelas X MIPA I SMAN I Ngemplak. Uji sumatif dilaksanakan untuk mengetahui keefektifan produk dalam meningkatkan keterampilan menyimak bahasa Jerman. Hasil penelitian ini berupa produk multimedia pembelajaran yang dinilai sangat baik pada saat uji alpha dan uji beta sehingga layak untuk digunakan pada uji sumatif. Keefektifan produk dibuktikan melalui perolehan hasil belajar peserta didik sebelum dan sesudah menggunakan multimedia pembelajaran.
\end{abstract}

Kata Kunci: Bahasa Jerman, keterampilan menyimak, multimedia pembelajaran

\section{DEVELOPING MULTIMEDIA LEARNING TO IMPROVE GERMAN LISTENING SKILL}

\begin{abstract}
This study aims to: (1) produce multimedia learning for German listening skill grade X on Kennenlernen materials, (2) determine the usefulness of the product in improving german listening skill of grade X student at Ngemplak Senior High School. This research and development study combined 3 models which are formulated by Borg \& Gall, Dick E Carey, and Allessi \& Trollip. The development steps were divided in 4 phases, namely preliminary studies, instructional development, multimedia development, and evaluation. Feasibility test consisted of two subject matter experts and two media experts in beta test and then beta test was done by 28 students in X MIPA 2. After that, a summative test involved 32 students in X MIPA 1 Ngemplak Senior High School. This test aimed to determine the effectiveness of this product in improving German listenng skill. The result of this research is in the form of multimedia leraning product which is considered excellent on alpha test and beta test so it is feasible to be used in summative test. The effectiveness of this product was proved by achievement test of the students, before and after using multimedia.
\end{abstract}

Keywords: German, listening skill, multimedia learning

doi http://dx.doi.org/10.21831/jitp.v6.1.15068 


\section{Pendahuluan}

Bahasa Jerman merupakan salah satu bahasa asing yang sekarang ini banyak dipelajari di dunia, termasuk Indonesia. Menurut survei yang dilakukan oleh Goetheinstitut, Badan Pendidikan Sekolah Luar Negeri (ZfA), dan Deutscher Akademischer Austauschdienst (DAAD) pada tahun 2015, di kawasan Asia Tenggara, Indonesia menduduki peringkat pertama dalam hal jumlah pembelajar bahasa Jerman dengan jumlah pembelajar sebanyak 187.000 orang. Jumlah pembelajar bahasa Jerman di sekolah-sekolah naik signifikan sebanyak 52.500 orang (Goethe-Institut, 2015). Data tersebut sudah menunjukan bahwa penguasaan akan bahasa ini menjadi sangat penting. Hal ini disebabkan oleh banyaknya informasi mengenai ilmu pengetahuan, baik dalam bidang ekonomi, politik, sosial, kesusastraan, seni, ataupun teknik yang ditulis dengan menggunakan bahasa Jerman. Selain itu, pada saat ini sudah terjalin kerja sama antara pemerintah Indonesia dan pemerintah Jerman dalam memajukan dunia pendidikan nasional. Hal ini dapat dilihat dengan banyak pelajar dari Indonesia yang sudah dikirim ke Jerman untuk belajar. Agar bahasa Jerman dapat dikuasai dengan baik oleh setiap peserta didik, proses pembelajaran harus dilaksanakan dengan baik.

Proses pembelajaran memiliki peranan yang cukup penting dalam penyelenggaraan pendidikan. Hal ini disebabkan karena proses pembelajaran memiliki peran dalam menghasilkan lulusan yang berkompeten. Oleh karena itu, guru sebagai fasilitator dituntut untuk menciptakan proses pembelajaran yang menarik, sehingga materi pembelajaran dapat dimengerti oleh semua peserta didik. Hal ini sesuai dengan amanat yang tertuang dalam Undangundang Nomor 20 Tahun 2003 pasal 3 (Presiden Republik Indonesia, 2003) tentang Sistem Pendidikan Nasional. Berdasarkan undang-undang tersebut maka dapat diketahui bahwa, pada proses pembelajaran, guru perlu menggali potensi dan menanamkan nilai-nilai luhur kepada peserta didik sehingga mereka dapat menjadi pribadi yang berkualitas dan dapat berguna bagi masyarakat. Hal tersebut berlaku bagi semua mata pelajaran yang diajarkan di setiap instansi pendidikan, termasuk mata pelajaran bahasa Jerman.

Pembelajaran bahasa Jerman sudah berlangsung di berbagai lembaga kebahasaan, baik itu lembaga formal maupun lembaga non-formal. Semua lembaga tersebut memfokuskan pembelajaran pada keempat keterampilan kebahasaan, yaitu keterampilan berbicara (sprechen), keterampilan menulis (schreiben), keterampilan membaca (lesen), dan keterampilan menyimak (hören). Keterampilan berbicara dan menulis dikategorikan ke dalam keterampilan aktif-produktif, sedangkan keterampilan menyimak dan keterampilan membaca dikategorikan ke dalam keterampilan aktif-reseptif. Pada lembaga formal, pengajaran bahasa Jerman tidak hanya mengacu pada kurikulum nasional yang berlaku melainkan juga mengacu pada Gemeinsamer Europäischer Referenzrahmen (GER).

GER merupakan standar kebahasaan Eropa yang menjadi patokan pengajaran bahasa Jerman di seluruh dunia. Berdasarkan GER, level atau tingkatan penguasaan bahasa Jerman dibagi ke dalam enam tingkatan, yaitu A1 dan A2 (tingkat dasar), B1 dan B2 (tingkat menengah), dan C1 dan C2 (tingkat mahir) (Widodo, 2012, p. 12). Hal ini sangat membantu peserta didik untuk menguasai bahasa Jerman karena materi ajar sudah disesuaikan dengan tingkat kebahasaan peserta didik. Pada umumnya, tingkatan pembelajaran bahasa Jerman di SMA digolongkan dalam tingkatan A1 dan A2 (tingkat dasar), walaupun terdapat juga beberapa SMA yang sudah mencapai tingkatan B1 (tingkat menengah). Agar dapat mencapai tingkatan-tingkatan tersebut secara optimal, proses pembelajaran menjadi salah satu faktor penting yang perlu diperhatikan oleh guru.

Proses pembelajaran bahasa, khususnya pembelajaran bahasa Jerman, guru harus lebih banyak memberikan kesempatan kepada peserta didik untuk berperan 
aktif. Contoh konkritnya, ketika guru menjelaskan tentang cara mengkonstruksi kalimat, peserta didik juga diberikan kesempatan untuk membuat kalimat sendiri sesuai dengan contoh yang sudah diberikan. Pada konteks pembelajaran keterampilan menyimak, peserta didik lebih banyak diperdengarkan wacana lisan sederhana berbahasa Jerman dan mengungkapkan kembali informasi penting dalam wacana tersebut. Dalam proses pembelajaran bahasa, ada aspek lain yang cukup penting untuk dipahami selain materi- materi yang berhubungan dengan kebahasaan. Aspek tersebut adalah budaya atau kultur dari penutur asli bahasa tersebut, dalam hal ini budaya atau kultur Jerman.

Belajar bahasa berarti belajar budaya. Ungkapan ini sering kali didengar ketika seseorang hendak mempelajari suatu bahasa asing. Secara eksplisit pernyataan tersebut mengandung makna bahwa pembelajaran bahasa asing bukan hanya terfokus pada pemahaman keterampilan berbahasa, melainkan juga terfokus pada pembelajaran latar belakang budaya dari bahasa yang dipelajari. Seseorang tidak dapat berkomunikasi dengan baik jika ia tidak memahami latar belakang budaya dari lawan bicaranya tersebut. Contohnya, ketika baru pertama kali bertemu dan berkomunikasi dengan orang Jerman, seseorang tidak boleh menggunakan kata " $d u$ " (kamu) melainkan "Sie" (anda) karena kata " $d u$ " dianggap kurang sopan bagi orang yang baru pertama kali berkenalan. Dari contoh singkat tersebut dapat diketahui bahwa pembelajaran bahasa asing juga mampu mengembangkan sikap toleransi dan saling menghargai antarkomunikator. Agar semua kom-penen pembelajaran tersebut dapat ter-capai, guru perlu mendesain proses pem-belajaran yang baik. Tetapi pada kenyataan-nya, masih terdapat masalah yang meng-hambat proses pembelajaran bahasa Jerman, seperti yang terjadi di kelas $X$ SMAN 1 Ngemplak, Sleman.

SMAN 1 Ngemplak merupakan salah satu SMA yang mengajarkan bahasa Jerman. Di SMA ini, bahasa Jerman dike- lompokan ke dalam program pilihan bahasa asing lainnya. Berdasarkan hasil wawancara dengan guru bidang studi bahasa Jerman, peserta didik kelas $X$ berada pada level kebahasaan A1. Menurut GER, kompotensi yang perlu dicapai oleh peserta didik adalah mampu memahami dan menggunakan ungkapan-ungkapan sederhana yang biasa digunakan dalam kehidupan sehari-hari dan kalimat yang sederhana untuk menjelaskan hal-hal konkrit. Peserta didik juga mampu memperkenalkan diri dan orang lain serta dapat bertanya, seperti dimana mereka tinggal, siapa yang mereka kenal atau apa yang mereka miliki. Selain itu, peserta didik juga mampu dapat menjawab pertanyaan-pertanyaan serupa yang ditujukan kepadanya (Widodo, 2012, p. 2012). Selain menanyakan tentang level kebahasaan peserta didik kelas $X$, peneliti juga menanyakan tentang jalanya proses pembelajaran bahasa Jerman.

Proses pembelajaran bahasa Jerman masih dilakukan dengan menggunakan metode ceramah. Ketika memulai proses pembelajaran, guru tidak menyampaikan tujuan atau kompetensi yang akan dicapai setelah mengikuti rangkaian proses pembelajaran bahasa Jerman. Guru langsung menyampaikan materi pembelajaran Bahasa Jerman. Selama proses pembelajaran berlangsung, guru tidak banyak memberikan kesempatan kepada peserta didik untuk membuat contoh kalimat yang sesuai dengan materi yang sedang dipelajari. Hal ini menyebabkan proses pembelajaran hanya berpusat pada guru (teacher center) sedangkan peserta didik hanya pasif mendengarkan setiap materi yang disampaikan oleh guru. Metode yang digunakan tersebut tentunya bertentangan dengan pendekatan komunikatif dalam pembelajaran bahasa. Pendekatan ini mengharuskan setiap peserta didik untuk berperan aktif selama proses pembelajaran berlangsung. Kurang efektifnya metode yang diguanakan guru selama proses pembelajaran bahasa Jerman dapat dilihat dari hasil angket yang disebarkan kepada peserta didik pada saat kegiatan studi pendahuluan. Sebanyak $65 \%$ peserta didik menja- 
wab bahwa mereka masih mengalami kesulitan dalam keterampilan menyimak bahasa Jerman, sedangkan sebanyak $60 \%$ menjawab bahwa metode yang digunakan guru pada saat menyampaikan materi pembelajaran bahasa Jerman kurang bervariasi. Jawaban dari peserta didik tersebut diperkuat dengan perolehan hasil pretest yang dilaksanakan di kelas X MIPA I SMAN 1 Ngemplak. Hasil pretest menunjukan bahwa rata-rata perolehan nilai peserta didik Kelas X adalah 60,87. Perolehan nilai tersebut tentunya belum mencapai Kriteria Ketuntasan Minimal (KKM) mata pelajaran bahasa Jerman yaitu 75 .

Berdasarkan hasil pengamatan yang sudah dilaksanakan pada saat proses pembelajaran bahasa Jerman berlangsung, masih terdapat beberapa peserta didik yang belum menguasai pengkonjugasian kata kerja yang disesuaikan dengan subyek dalam kalimat, baik pengkonjugasian kata kerja beraturan (Regelmaßige Verben) maupun kata kerja tidak beraturan (UnregeImaßige Verben). Jika dilihat dari urutan materi pembelajaran bahasa Jerman untuk peserta didik kelas X SMA, pengkonjugasian kata kerja merupakan materi dasar sebagai pijakan sebelum mempelajari materi-materi bahasa Jerman yang lain. Apabila materi ini belum dikuasai maka dapat dipastikan peserta didik akan kesulitan untuk menguasai materi bahasa Jerman selanjutnya. Selain itu, masih terdapat beberapa peserta didik yang belum menguasai kosakata dalam bahasa Jerman. Hal ini dapat terlihat ketika peserta didik diminta untuk melengkapi kalimat rumpang dengan kata kerja yang telah disediakan. Peserta didik masih mengalami kesulitan dalam memilih kata kerja yang sesuai dengan konteks kalimat. Permasalahan lain yang dijumpai adalah kurangnya penguasaan akan ujaran atau redemittel dalam bahasa Jerman, khususnya pada tema Kennenlernen (Berkenalan). Seperti yang diketahui bahwa ujaran atau redemittel merupakan pedoman standar bagi setiap peserta didik untuk berkomunikasi dalam bahasa Jerman. Permasalahan-permasalahan yang telah dikemu- kakan tersebut sangat berdampak terhadap penguasaan keempat keterampilan berbahasa, khususnya pada keterampilan menyimak (hören).

Keterampilan menyimak merupakan salah satu keterampilan yang cukup sulit untuk dikuasai dalam bahasa Jerman. Hal ini disebabkan karena bahasa Jerman masih kurang begitu populer di kalangan peserta didik yang mempelajari bahasa Asing. Selain gramatiknya yang berbeda dengan bahasa Inggris (bahasa linguafranka), bahasa Jerman juga memiliki perbedaan dari aspek morfologi, sintaks, ataupun sistem fonologi sehingga menyulitkan peserta didik dalam menangkap dan memahami maksud yang diungkapkan. Agar permasalahan di atas dapat teratasi maka guru dapat memanfaatkan teknologi yang semakin berkembang.

Pada saat ini, ilmu pengetahuan dan teknologi (IPTEK) telah berkembang pesat sehingga memudahkan guru untuk mendesain pembelajaran yang lebih bervariatif. Salah satu langkah yang dapat dilakukan oleh guru mata pelajaran bahasa Jerman adalah mengembangkan multimedia pembelajaran bahasa Jerman yang lebih difokuskan pada salah satu pembelajaran keterampilan berbahasa, khususnya pembelajaran keterampilan menyimak. Hal tersebut sesuai dengan salah satu tujuan dari Teknologi Pendidikan, yaitu untuk memfasilitasi belajar.

Teknologi Pendidikan adalah studi dan etika praktik untuk memfasilitasi pembelajaran dan meningkatkan kinerja dengan menciptakan, menggunakan, dan mengelola proses teknologi yang sesuai dan sumber daya (Januszewski \& Molenda, 2008, p. 1). Pada definisi ini, pengembangan multimedia pembelajaran termasuk dalam create (kreasi) dan using (penggunaan). Tujuan utama yang ingin dicapai dalam definisi terbaru teknologi pembelajaran adalah memfasilitasi belajar dan memperbaiki kinerja. Dengan dikembangkannya multimedia, permasalahan yang sedang dihadapi dalam proses pembelajaran dapat diselesaikan dengan baik, khusunya permasa- 
lahan dalam proses pembelajaran keterampilan menyimak bahasa Jerman.

Pengembangan dan penerapan multimedia pembelajaran sangat penting untuk dilaksanakan. Hal ini mengingat banyaknya kelebihan dari media itu sendiri dalam menunjang proses pembelajaran. Kelebihankelebihan tersebut antara lain, mengkonkritkan konsep-konsep yang abstrak, membangkitkan motivasi, memfungsikan seluruh indera peserta didik, mendekatkan dunia konsep atau teori dengan realitas (Mukminan, 2004, p. 63). Dengan semakin berkembangnya ilmu pengetahuan dan teknologi, semua orang dapat meggabungkan beberapa unsur media ke dalam satu tampilan komputer. Gabungan dari beberapa unsur media dikenal juga dengan istilah multimedia. Penggunaan multimedia dalam pembelajaran bertujuan agar materi pembelajaran yang disampaikan dapat dikemas lebih menarik sehingga memudahkan peserta didik memahami konten materi yang disampaikan.

Selain alasan yang dikemukakan di atas, alasan lain pentingnya dikembangkan multimedia pembelajaran berbasis flash karena multimedia pembelajaran ini dikembangkan dengan menggabungkan beberapa unsur media seperti teks, gambar, audio, dan video sehingga lebih menarik dan inovatif. Peserta didik juga dapat belajar secara mandiri dengan menggunakan multimedia pembelajaran. Peserta didik mampu mengoperasikan multimedia secara mandiri tanpa perlu didampingi secara intens oleh guru mata pelajaran. Selain itu, ketika peserta didik mengerjakan latihan atau kuis yang terdapat dalam multimedia, mereka dapat mengetahui feedback secara langsung. Hal ini tentunya sangat membantu peserta didik dalam meningkatkan kemampuan dan keterampilan, khususnya dalam keterampilan menyimak bahasa Jerman.

Penelitian yang dilakukan oleh James Kulik (Heinich, Molenda, Russell, \& Smaldino, 1996, p. 217) menunjukkan bahwa pembelajaran berbasis teknologi dapat meningkatkan rata-rata prestasi peserta didik $10-18 \%$ jika dibandingkan dengan menggunakan pembelajaran konvensional. Hal senada juga diungkapkan oleh Prismanata \& Ismaniati (2017, p. 110) yang menyebutkan bahwa penggunaan multimedia dalam pembelajaran dapat meningkatkan hasil belajar secara signifikan jika dibandingkan dengan pembelajaran biasa. Selain data penelitian tersebut, faktor lain yang menjadi alasan mengembangkan multimedia dalam proses pembelajaran adalah hasil angket analisis kebutuhan peserta didik. Sebanyak $90 \%$ peserta didik menginginkan proses pembelajaran dengan menggunakan komputer. Peserta didik menyebutkan bahwa pembelajaran dengan menggunakan komputer dapat menumbuhkan motivasi untuk belajar. Berdasarkan hasil penelitian dan fakta lapangan tersebut, penggunaan teknologi dalam proses pembelajaran tentunya sangat membantu guru dalam menyelesaikan permasalahan konkrit yang sedang terjadi, khususnya permasalahan dalam proses pembelajaran keterampilan menyimak bahasa Jerman. Oleh karena itu, peneliti sangat tertarik untuk mengembangkan Multimedia pada pembelajaran keterampilan menyimak bahasa Jerman Kelas X SMAN 1 Ngemplak dengan tema Berkenalan (Kennenlernen), semester ganjil. Adapun sub-tema yang digunakan adalah Begrüßung, Name, Herkunft, Wohnort, Alter,Beruf, dan Hobby.

\section{Metode Penelitian}

Jenis Penelitian yang digunakan dalam penelitian ini adalah model penelitian pengembangan atau Research and Development $(R \mathcal{E} D)$ untuk menghasilkan multimedia pada pembelajaran keterampilan menyimak bahasa Jerman kelas X SMAN 1 Ngemplak. Penelitian ini menggunakan perpaduan 3 model pengembangan yang dikemukakan oleh Borg \& Gall, Dick, Carey, \& Carey, dan Allesi \& Trollip. Tahapan penelitian pengembangan ini menggunakan model penelitian yang dikemukakan oleh Borg \& Gall, desain instruksional menggunakan model yang dikemukakan oleh Dick, Carey, \& Carey, sedangkan pengem- 
bangan multimedia menggunakan model pengembangan yang dikemukakan oleh Alessi \& Trollip. Dari paparan tersebut, maka tahapan pada penelitian ini digambarkan pada Gambar 1.

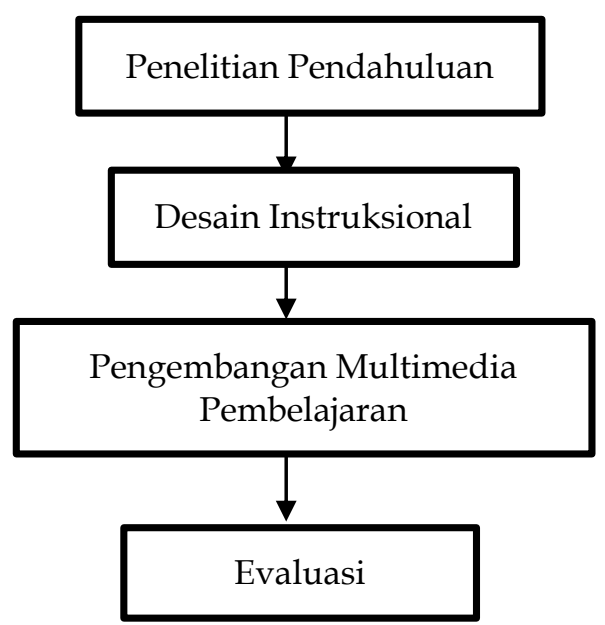

Gambar 1. Proses Pengembangan Multimedia Pembelajaran Keterampilan Menyimak Bahasa Jerman

Tahap penelitian pendahuluan dibagi menjadi dua tahap, yaitu studi lapangan dan studi pustaka. Pada tahap desain instruksional, penelitian ini dibagi ke dalam tujuh tahap, antara lain, melakukan analisis instruksional, menganalisis pembelajar dan konteks, merumuskan tujuan pembelajaran khusus, mengembangkan instrument penilaian,menyusun strategi pembelajaran, mengembangkan dan memilih materi, dan membuat flowcharts dan storyboard.

Tahap pengembangan multimedia pembelajaran terdiri dari 6 tahap, antara lain, menyiapkan teks, menulis kode program, membuat grafis, merekam audio dan membuat video, menyatukan bahan-bahan, dan menyiapkan materi pendukung. Sedangkan tahap evaluasi terdiri dari dua tahap, yaitu uji alpha (Expert Judgment) dan uji beta (uji lapangan.

Subjek yang digunakan dalam penelitian ini dibagi ke dalam 2 kelompok, yaitu kelompok kelas uji beta dan kelompok kelas uji sumatif. Subyek uji beta adalah sebanyak 28 orang peserta didik kelas X MIPA 2 SMAN 1 Ngemplak, sedangkan subyek uji sumatif adalah sebanyak 32 orang peserta didik di kelas X MIPA I SMAN 1 Ngemplak. Sebelum produk multimedia diuji coba dan digunakan dalam proses pembelajaran, produk terlebih dahulu divalidasi oleh 2 ahli materi dan 2 ahli media. Proses ini bertujuan untuk mengetahui kelayakan produk, baik dari aspek materi maupun aspek media. Agar semua data penelitian dapat dikumpulkan dengan baik, maka diperlukan instrumen evaluasi yang mampu mengemas keseluruhan aspek yang perlu dinilai (Mawarni \& Muhtadi, 2017, p. 88).

Pada penelitian ini, instrumen yang digunakan untuk mengumpulkan data-data penelitian antara lain, kuesioner untuk ahli media, kuesioner untuk pengguna, serta soal pretest dan posttest. Data penelitian pengembangan ini adalah data kualitatif dan data kuantitatif. Data kualitatif diperoleh dari masukan dan saran ahli materi, ahli media, dan peserta didik. Masukan dan saran tersebut digunakan untuk merevisi produk yang telah dikembangkan. Data kuantitatif dalam penelitian ini berupa penilaian yang diberikan oleh ahli media, ahli materi, dan peserta didik yang telah dikonversikan ke dalam skala Likert dengan skala 5. Pada skala ini, produk yang dikembangkan dikatakan layak jika penilaian yang diberikan minimal 4 atau berkategori baik. Skor dan kriteria penilaian skala Likert diuraikan pada Tabel 1.

Tabel 1. Skor dan Kriteria Penilaian

\begin{tabular}{ccc}
\hline Nilai & Skor & Kategori \\
\hline $\mathrm{X}>\mathrm{Xi}+1,50 \mathrm{SDi}$ & 5 & Sangat Baik \\
$\mathrm{Xi}+0,50 \mathrm{SDi}<\mathrm{X} \leq \mathrm{Xi}+$ & 4 & Baik \\
$1,50 \mathrm{SDi}$ & & Cukup \\
$\mathrm{Xi}-0,50 \mathrm{SDi}<\mathrm{X} \leq \mathrm{Xi}+$ & 3 & Kurang \\
$1,50 \mathrm{SDi}$ & 2 & $\begin{array}{c}\text { Sangat } \\
\text { Kurang }\end{array}$ \\
$\mathrm{Xi}-0,50 \mathrm{SDi}<\mathrm{X} \leq \mathrm{Xi}-$ & 1 & \\
$1,50 \mathrm{SDi}$ & & \\
$\mathrm{X} \leq \mathrm{Xi}-1,50$ SDi & 1 & \\
\end{tabular}

Sumber: Sudijono (2013, p. 329)

Informasi mengenai keefektifan multimedia pembelajaran diperoleh melalui peroleh hasil pretest dan postest peserta didik. Sebelum digunakan, insterumen tes 
terlebih dahulu divalidasi dan diujicobakan kepada peserta didik. Uji coba dilakukan untuk mengetahui indeks kesukaran dan indeks daya pembeda setiap butir soal. Jumlah butir soal yang diujicobakan sebanyak 30 soal dan berbentuk multiple choice dengan menggunakan 4 opsi jawaban. Tes yang telah diujicobakan kemudian diolah dengan menggunakan bantuan aplikasi Iteman versi 3.0. Output tiap-tiap butir soal dapat dilihat pada lampiran. Tingkat kesukaran dapat ditentukan dengan menganalisis kolom prop. correct, sedangkan daya pembeda dapat ditentukan dengan melihat kolom point biserial. Kriteria setiap aspek dapat dilihat pada Tabel 2 dan 3.

Tabel 2. Kriteria Indeks Kesukaran Butir Soal

\begin{tabular}{ll}
\hline Indeks Kesukaran & Kategori \\
\hline $0,00 \leq 0,30$ & Sukar \\
$0,31 \leq \mathrm{P} \leq 0,70$ & Sedang \\
$0,71 \leq 1,00$ & Mudah \\
\hline
\end{tabular}

Sumber: Arikunto (2012, p. 225)

Tabel 3. Kriteria Indeks Daya Pembeda

\begin{tabular}{ll}
\hline Indeks Daya Pembeda & Kategori \\
\hline $0,71<1,00$ & Sangat Baik \\
$0,41<\mathrm{D} \leq 0,70$ & Baik \\
$0,21<\mathrm{D} \leq 0,40$ & Cukup \\
$0,00 \leq 0,20$ & Jelek \\
\hline
\end{tabular}

Sumber: Arikunto (2012, p. 232)

Pengambilan kesimpulan tentang keefektifan multimedia pembelajaran dilakukan berdasarkan perhitunagn $N$-gain atau normalized gain. Hake (Meltzer, 2002, p. 1261) mengungkapkan bahwa $N$-gain atau normalized gain adalah perbandingan gain rata-rata sebenarnya dengan gain rata-rata maksimum. Persamaan yang digunakan antara lain sebagai berikut:

$$
N \text {-gain }(\mathrm{g})=\frac{\text { skor akhir-skor awal }}{\text { skor maksimum-skor awal }}
$$

Hasil perhitungan $\mathrm{N}$-gain yang diperoleh kemudian dikelompokan ke dalam tiga kategori seperti pada Tabel 4 .
Tabel 4. Kategori Tingkat N-gain

\begin{tabular}{ll}
\hline N-gain & Kategori \\
\hline $\mathrm{g}<0,3$ & Rendah \\
$0,3 \leq \mathrm{g} \leq 0,7$ & Sedang \\
$\mathrm{g}>0,7$ & Tinggi \\
\hline
\end{tabular}

Sumber: Sari \& Apriani (2014, p. 138)

\section{Hasil dan Pembahasan}

Hasil Pengembangan Instrumen Penilaian

Pengembangan instrumen penliaian bertujuan untuk mengukur pemahaman peserta didik dalam pembelajaran keterampilan menyimak bahasa Jerman. Instrumen penilaian disusun berdasarkan tujuan pembelajaran khusus yang telah dirumuskan. Penilain terhadap pemahaman peserta didik dilakukan dalam 2 tahap, yaitu pretest dan postest. Pretest dilakukan sebelum peserta didik belajar dengan menggunakan multimedia, sedangkan postest dilakukan setelah peserta didik belajar dengan menggunakan multimedia. Sebelum digunakan, soal-soal tersebut terlebih dahulu diujicobakan untuk mengetahui validitas tiap butir soal.

Pada awalnya, soal pretest dan posttest berjumlah 30 butir soal yang berbentuk multiple choice. Setelah dilakukan uji coba, maka jumlah soal yang dinyatakan gugur sebanyak 5 butir soal, sedangkan 25 butir soal dinyatakan lolos uji. Adapun uji coba butir tes diberikan kepada peserta didik yang sudah mempelajari materi Kennenlernen, yaitu peserta didik kelas XI MIPA 2 yang berjumlah 32 orang. Hasil uji item berdasarkan kategori indeks kesukaran dan indeks daya beda dapat dilihat pada Tabel 5 dan Tabel 6.

Secara keseluruhan, total indeks daya kesukaran butir soal diperoleh skor sebesar 0,400 sehingga dikategorikan "Sedang". Pada kategori indeks daya beda, total skor yang diperoleh sebesar 0,544 sehingga dikategorikan "Baik". Sedangkan koefisien reliabilitas soal diperoleh skor sebesar 0,758 sehingga dikategorikan "Sangat Tinggi". 
Tabel 5. Indeks Kesukaran

\begin{tabular}{ll}
\hline $\begin{array}{l}\text { Kategori } \\
\text { Soal }\end{array}$ & \multicolumn{1}{c}{ No. Soal } \\
\hline Sukar & No. 10, 13, 17, 18, 27 \\
Sedang & No.1, 2, 4, 5, 6, 7, 8, 9, 14, 16, \\
& $\begin{array}{l}19,20,22,25,28 \\
\text { Mudah }\end{array}$ \\
& No. 3, 11, 12, 15, 21, 23, 24, \\
& $26,29,30$ \\
\hline
\end{tabular}

Sumber: Hasil Perhitungan

Tabel 6. Indeks Daya Beda

\begin{tabular}{ll}
\hline \multicolumn{1}{c}{$\begin{array}{c}\text { Kategori } \\
\text { Soal }\end{array}$} & \multicolumn{1}{c}{ No. Soal } \\
\hline \multirow{2}{*}{ Baik } & No. 3, 4, 5, 7, 11, 12, 14, 16, \\
& $19,21,24,30$ \\
Cukup & No. 1, 2, 8, 9, 15, 20, 22, 23, \\
Jelek & No. 26, 28, 29 10, 13, 17, 18, 27 \\
\hline
\end{tabular}

Sumber: Hasil Perhitungan

Hasil Validasi Produk

Uji coba produk dilakukan melalui 2 tahap, yaitu uji alpha dan uji beta. Uji alpha dilakukan oleh 2 orang ahli materi dan 2 ahli media, sedangkan uji beta melibatkan 28 orang peserta didik kelas X MIPA 2 SMAN I Ngemplak.

Validasi terhadap materi yang digunakandalam multimedia pembelajaran keterampilan menyimak bahasa Jerman dilakukan oleh 2 orang ahli materi bahasa Jerman. Data penilaian dari ahli materi diperoleh melalui lembar instrumen dengan penilaian berskala Likert. Selain memberikan penilaian, ahli materi juga memberikan masukan dan saran terhadap setiap perangkat pembelajaran yang digunakan dalam proses pembelajaran. Perangkat pembelajaran tersebut antara lain, silabus, Rencana Pelaksanaan Pembelajaran (RPP), kisi-kisi tes, pretest, dan postes. Berikut ini disajikan hasil penilaian dari validator materi terhadap materi yang terdapat dalam multimedia.

Tabel 7 menunjukan bahwa, pada aspek kualitas konten dan tujuan validator Materi 1 dan Validator Materi 2 memberikan skor dengan rata-rata 4,22 sehingga aspek tersebut dikategorikan "Sangat Baik". Selanjutnya, pada aspek kualitas pembela- jaran, ahli materi 1 dan ahli materi 2 memberikan skor dengan rata-rata 4,55 sehingga dapat dikategorikan "Sangat Baik". Secara keseluruhan, rerata skor multimedia untuk pembelajaran keterampilan menyimak bahasa Jerman dari aspek materi adalah 4,40. Berdasarkan rerata tersebut maka aspek materi dalam multimedia dapat dikategorikan "Sangat Baik". Berdasarkan perolehan skor rata-rata tersebut maka dapat disimpulkan bahwa multimedia pembelajaran dikatakan layak dari aspek materi.

Tabel 7. Rerata Skor Hasil Validasi Ahli Materi

\begin{tabular}{clcc}
\hline No. & \multicolumn{1}{c}{ Aspek } & $\begin{array}{c}\text { Rata- } \\
\text { rata }\end{array}$ & Kriteria \\
\hline 1. & $\begin{array}{l}\text { Kualitas } \\
\text { Konten dan } \\
\text { Tujuan }\end{array}$ & 4,22 & Sangat Baik \\
2. & $\begin{array}{l}\text { Kualitas } \\
\text { Pembelajaran } \\
\text { Rerata }\end{array}$ & 4,55 & Sangat Baik \\
& 4,40 & Sangat Baik \\
\hline
\end{tabular}

Sumber: Hasil Perhitungan

Validator materi 1 dan validator materi 2 menyatakan bahwa multimedia untuk pembelajaran keterampilan menyimak bahasa Jerman layak untuk digunakan dengan revisi sesuai saran dan masukan. Adapun saran dan masukan tersebut antara lain, menyederhanakan tujuan pembelajaran, menyajikan kuis tentang keterampilan menyimak, menyesuaikan kuis dengan submateri, mengurutkan video dan audio sesuai sub-materi pembelajaran, menambahkan materi tentang akkusativ dan dativ, menyesuaikan contoh dengan konten yang disajikan, mengurutkan komponen-komponen dalam peta konsep, memberikan penjelasan tentang perbedaan antara bestimmter artikel dan unbestimmter artikel, dan mengurutkan sajian materi. Selain memperoleh penilaian dari aspek materi, multimedia pembelajaran keterampilan menyimak bahasa Jerman juga memperoleh penilaian dari aspek media.

Validasi terhadap aspek media dilakukan oleh 2 orang ahli media. Data vali- 
dasi oleh ahli media diperoleh melalui lembar instrumen dengan penilaian berskala Likert. Adapun komponen-komponen yang termuat dalam instrumen meliputi, pengenalan program, kontrol pengguna, presentasi informasi, ketersediaan bantuan, akhir program, dan kriteria multimedia pembelajaran interaktif. Setiap komponen tersebut terdapat beberapa pertanyaan yang nantinya menjadi bahan penilaian terhadap produk multimedia untuk pembelajaran keterampilan menyimak bahasa Jerman. Hasil penilaian dari ahli media dijabarkan pada Tabel 8.

Tabel 8. Rerata Skor Validasi Ahli Media

\begin{tabular}{|c|c|c|c|}
\hline No. & Aspek & $\begin{array}{c}\text { Rata- } \\
\text { rata }\end{array}$ & Kriteria \\
\hline 1. & $\begin{array}{l}\text { Pengenalan } \\
\text { Program }\end{array}$ & 3,90 & Baik \\
\hline 2. & Kontrol Pengguna & 4,00 & Baik \\
\hline 3. & Presentasi Informasi & 4,32 & $\begin{array}{l}\text { Sangat } \\
\text { Baik }\end{array}$ \\
\hline 4. & $\begin{array}{l}\text { Ketersediaan } \\
\text { Bantuan }\end{array}$ & 4,00 & Baik \\
\hline 5. & Akhir Program & 4,77 & $\begin{array}{l}\text { Sangat } \\
\text { Baik }\end{array}$ \\
\hline 6. & $\begin{array}{l}\text { Kriteria Multimedia } \\
\text { Pembelajaran } \\
\text { Interaktif }\end{array}$ & 3,91 & Baik \\
\hline & Rata-rata & 4,16 & $\begin{array}{l}\text { Sangat } \\
\text { Baik }\end{array}$ \\
\hline
\end{tabular}

Sumber: Hasil Perhitungan

Tabel 8 menunjukan bahwa, pada aspek pengenalan program, validator media 1 dan validator media 2 memberikan penilaian dengan rata-rata skor 3,90 atau dikategorikan baik, aspek kontrol pengguna rerata skor yang diperoleh 4,00 atau dikategorikan baik, aspek presentasi informasi rerata skor yang diperoleh adalah 4,32 atau dikategorikan sangat baik, aspek ketersediaan bantuan rerata skor yang diperoleh 4,00 atau dikategorikan baik, aspek akhir program rerata skor yang diperoleh adalah 4,77 atau dikategorikan sangat baik, dan aspek kriteria multimedia pembelajaran interaktif rerata skor yang diperoleh 3,91 atau dikategorikan baik. Secara keseluruh- an, multimedia untuk pembelajaran keterampilan menyimak bahasa Jerman memperoleh skor rata-rata 4,16 sehingga dikategorikan "Sangat Baik". Berdasarkan perolehan skor rata-rata tersebut maka dapat disimpulkan bahwa multimedia pembelajaran dikatakan layak dari aspek media.

Validator media 1 dan validator media 2 menyatakan bahwa multimedia untuk pembelajaran keterampilan menyimak bahasa Jerman layak untuk digunakan dengan revisi sesuai saran dan masukan. Adapun saran dan masukan tersebut antara lain, title page perlu ditambah informasi tentang target user, posisi menu petunjuk penggunaan seharusnya dipisah dari main menu sehingga tidak menyulitkan user, tombol next dan back sebaiknya diletakan secara berdekatan, pada Menu Petunjuk Penggunaan perlu diberikan judul serta target user, redaksi kalimat pada Menu Petunjuk Penggunaan sebaiknya digunakan kalimat yang tidak terlalu panjang, pilihan warna pada background sebaiknya digunakan warna yang tidak terlalu terang sehing-ga tidak menggagu fokus user, setiap audio dan video perlu disertakan dengan referensi, dan peta konsep pada menu materi sebaiknya diperbesar. Setelah multimedia dikatakan layak, baik dari aspek materi dan media, multimedia selanjutnya diujicobakan kepada peserta didik (Uji Beta).

Uji beta merupakan uji coba produk kepada target pengguna multimedia pembelajaran keterampilan menyimak bahasa Jerman, yaitu kelas X SMA. Uji beta dilaksanakan untuk memperoleh penilaian dan masukan dari peserta didik yang digunakan sebagai acuan untuk merevisi produk. Hal ini bertujuan agar produk layak untuk digunakan dalam proses pembelajaran keterampilan menyimak bahasa Jerman. Aspekaspek yang perlu diilai pada uji beta antara lain, kualitas konten, kualitas pembelajaran, pengenalan program, kontrol pengguna, presentasi informasi, ketersediaan bantuan, dan akhir program. Adapun uji beta dilakukan di kelas X MIPA 2 SMAN 1 Ngemplak yang berjumlah 28 orang peserta didik. 
Data hasil rekapitulasi hasil angket pada uji beta disajikan pada Tabel 9 .

Tabel 9 menunjukan bahwa, aspek kualitas konten dan tujuan rata-rata skor diperoleh adalah 4,07 atau dikategorikan sangat baik, aspek kualitas pembelajaran rerata skor yang diperoleh 4,13 atau dikategorikan sangat baik, aspek pengenalan program rerata skor yang diperoleh 4,11 atau dikategorikan sangat baik, aspek kontrol pengguna rerata skor yang diperoleh 4,07 atau dikategorikan sangat baik, aspek presentasi informasi rerata skor yang diperoleh 4,17 atau dikategorikan sangat baik, aspek ketersediaan bantuan rerata skor yang diperoleh 4,04 atau dikategorikan sangat baik, aspek akhir program, rerata skor yang diperoleh 4,18 atau dikategorikan sangat baik. Rerata skor penilaian tehadap multimedia adalah 4,13 sehingga dikategorikan sangat baik.

Tabel 9. Rerata Skor Hasil Uji Beta

\begin{tabular}{clcc}
\hline No. & \multicolumn{1}{c}{ Aspek } & Rerata & Kriteria \\
\hline 1. & $\begin{array}{l}\text { Kualitas Konten } \\
\text { dan Tujuan }\end{array}$ & 4,07 & $\begin{array}{c}\text { Sangat } \\
\text { Baik }\end{array}$ \\
2. & $\begin{array}{l}\text { Kualitas } \\
\text { Pembelajaran }\end{array}$ & 4,13 & $\begin{array}{c}\text { Sangat } \\
\text { Baik }\end{array}$ \\
3. & $\begin{array}{l}\text { Pengenalan } \\
\text { Program }\end{array}$ & 4,11 & $\begin{array}{c}\text { Sangat } \\
\text { Baik }\end{array}$ \\
4. & $\begin{array}{l}\text { Kontrol Pengguna } \\
\text { Sangat } \\
\text { Baik }\end{array}$ \\
5. & $\begin{array}{l}\text { Presentasi } \\
\text { Informasi }\end{array}$ & 4,17 & $\begin{array}{c}\text { Sangat } \\
\text { Baik }\end{array}$ \\
6. & $\begin{array}{l}\text { Ketersediaan } \\
\text { Bantuan }\end{array}$ & 4,04 & $\begin{array}{c}\text { Sangat } \\
\text { Baik }\end{array}$ \\
7. & Akhir Program & 4,18 & $\begin{array}{c}\text { Sangat } \\
\text { Baik }\end{array}$ \\
& Rata-rata & 4,13 & $\begin{array}{c}\text { Sangat } \\
\text { Baik }\end{array}$ \\
\hline
\end{tabular}

Sumber: Hasil Perhitungan

Secara keseluruhan, penilaian yang diperoleh pada uji beta menunjukan bahwa multimedia pembelajaran keterampilan menyimak bahasa Jerman layak untuk digunakan pada proses pembelajaran bahasa Jerman. Setelah produk melalui uji beta dan dikatakan layak, maka tahap selanjutnya adalah menerapkan produk tersebut ke dalam pembelajaran (Uji Sumatif). Hal ini bertujuan untuk mengetahui keefektifan penggunaan multimedia pembelajaran dalam meningkatkan keterampilan menyimak bahasa Jerman.

\section{Hasil Revisi Produk}

Tahapan revisi produk dilakukan setelah produk multimedia pembelajaran melalui uji alpha dan uji beta. Pada tahapan ini, pengembang merevisi produk sesuai dengan saran dan masukan dari ahli materi, ahli media, dan peserta didik. Revisi atau perbaikan produk penting untuk dilakukan. Hal ini bertujuan agar produk yang telah dikembangkan layak untuk digunakan secara luas dan berkualitas, baik dari sisi tampilan maupun kemasan materi. Berdasarkan data yang diperoleh dari ahli materi maka dilakukan revisi tahap awal, antara lain, penyederhanaa tujuan pembelajaran, penyajian kuis tentang keterampilan menyimak, penyesuaian kuis dengan submateri, pengurutan video dan audio sesuai sub-materi, penambahan materi akkusativ dan dativ, penyesuaian contoh dengan konten, pengurutan komponen dalam peta konsep, pemberian penjelasan tentang perbedaan antara Bestimmter Artikel dan Unbestimmter Artikel, pengurutan menu materi, sedangkan revisi pada aspek materi, antara lain, penambahan informasi User pada Title Page, penambahan pilihan Main Menu, penambahan tingkat kontras pada background, penyesuaian tata letak tombol Next dan Back, dan penambahan referensi pada audio dan video.

Revisi tahap selanjutnya diperoleh dari masukan peserta didik pada saat melakukan uji beta. Berdasarkan masukan tersebut maka revisi yang dilakukan antara lain, penambahan materi pembelajaran keterampilan menyimak bahasa Jerman, penambahan video tentang tema Kennenlernen, dan perbaikan soal no 23 pada Menu Kuis.

\section{Uji Sumatif}

Uji sumatif dilakukan dengan 2 cara, yaitu melalui pretest dan postest. Pretest dilakukan pada awal pertemuan sebelum 
peserta didik belajar dengan menggunakan multimedia Sedangkan postest dilakukan setelah peserta didik belajar dengan menggunakan multimedia. Adapun pretest dan postest diberikan kepada peserta didik kelas $X$ MIPA I yang berjumlah 32 orang. Hasil pretest dan postest peserta didik dapat diihat pada Tabel 10.

Tabel 10 menunjukkan bahwa, nilai tertinggi yang diraih oleh peserta didik pada pretest adalah 80 , sedangkan nilai terendah adalah 52. Rerata perolehan nilai pretest adalah 60,87 . Pada postest, nilai maksimum yang diperoleh oleh peserta didik adalah 98, sedangkan nilai terendah adalah 72 . Adapun rerata nilai postest peserta didik adalah 83,37 .

Tabel 10. Hasil Perhitungan Pretest dan Postest

\begin{tabular}{lcc}
\hline Pretest & Maksimum & 80 \\
& Minimum & 52 \\
& Rerata & 60,87 \\
\hline Postest & Maksimum & 98 \\
& Minimum & 72 \\
& Rerata & 83,37 \\
\hline N-gain & Maksimum & 0,92 \\
& Minimum & 0,38 \\
& Rerata & 0,57 \\
\hline Frekuensi & Tinggi & $7(21,88 \%)$ \\
Kriteria N-gain & Sedang & 25 \\
& & $(78,13 \%)$ \\
& Rendah & $0(\%)$ \\
& Total & $32(100 \%)$ \\
\hline
\end{tabular}

Sumber: Hasil Perhitungan

Setelah diperoleh nilai rerata secara keseluruhan pretest dan postest, langkah selanjutnya adalah menghitung $N$-gain. Hasil perhitungan $\mathrm{N}$-gain menunjukan bahwa nilai maksimum yang diperoleh peserta didik adalah 0,98 , sedangkan nilai minimum adalah 0,38 . Rerata perolehan $N$-gain peserta didik secara keseluruhan adalah 0,57 . Secara keseluruhan, peserta didik yang memperoleh skor dengan kategori tinggi sebanyak 7 $(21,88 \%)$ orang, sedangkan peserta didik yang memperoleh skor dengan kategori sedang sebanyak $25(78,13 \%)$ orang. Berdasarkan perolehan $\mathrm{N}$-gain tersebut dapat disim- pulkan bahwa pembelajaran dengan menggunakan multimedia efektif dalam meningkatkan hasil belajar peserta didik, khusunya dalam pembelajaran keterampilan menyimak bahasa Jerman.

\section{Simpulan}

Berdasarkan hasil penelitian dan pembahasan dapat disampaikan simpulan sebagai berikut. Multimedia pembelajaran keterampilan menyimak bahasa Jerman merupakan produk yang dikembangkan sebagai salah satu sumber belajar pada mata pelajaran bahasa Jerman di kelas X SMAN 1 Ngemplak, khususnya pada pembelajaran keterampilan menyimak. Uji kelayakan terhadap produk multimedia dilakukan melalui 2 tahapan, yaitu uji Alpha dan uji Beta. Uji Alpha atau Expert Judgement dilakukan oleh 2 ahli materi dan 2 ahli media. Rerata penilaian ahli materi terhadap multimedia pembelajaran keterampilan menyimak bahasa Jerman adalah 4,40 atau dikategorikan sangat baik, sedangkan rerata penilaian ahli media adalah 4,16 atau dikategorikan sangat baik. Uji beta dilakukan dikelas X MIPA 2 SMAN 1 Ngemplak dengan melibatkan 28 orang peserta didik. Rerata penilaian peserta didik terhadap produk pembelajaran adalah 4,13 atau dikategorikan sangat baik. Berdasarkan penilaian tersebut maka multimedia pembelajaran keterampilan menyimak bahasa Jerman memiliki kualitas yang baik, baik dari aspek materi maupun dari aspek media, sehingga layak untuk digunakan dalam proses pembelajaran keterampilan menyimak bahasa Jerman.

Uji keefektifan multimedia dilakukan dengan cara membandingkan perolehan hasil pretest dan postest peserta didik. Rerata perolehan hasil pretest adalah 60,87 , sedangkan rerata perolehan postest adalah 83,37 . Adapaun rerata $N$-gain antara pretest dan postest adalah 0,57 atau dikategorikan sedang. Secara keseluruhan, peserta didik yang memperoleh skor dengan kategori tinggi sebanyak 7 orang $(21,88 \%)$, sedangkan peserta didik yang memperoleh skor dengan kategori sedang sebanyak 25 orang 
$(78,13 \%)$. Hasil perhitungan tersebut menunjukkan bahwa multimedia pembelajaran efektif dalam meningkatkan pembelajaran keterampilan menyimak bahasa Jerman.

Berdasarkan penelitian dan pengembangan terhadap multimedia pembelajaran keterampilan menyimak bahasa Jerman maka dapat disarankan beberapa hal berikut, diantaranya, (1) multimedia pembelajaran keterampilan menyimak bahasa Jerman diimplementasikan pada materi Kennenlernen (Berkenalan) kelas X SMA. Multimedia tersebut dapat digunakan sebagai media pembelajaran oleh guru dan dapat digunakan sebagai salah satu sumber belajar oleh peserta didik untuk kegiatan belajar mandiri, (2) multimedia pembelajaran perlu diimplementasikan lebih lanjut pada cakupan yang lebih luas agar dapat diidentifikasi kelemahan dan kekurangan produk dalam proses pembelajaran, (3) materi yang digunakan sebagai konten dalam multimedia perlu ditambahkan. Hal ini bertujuan agar proses pembelajaran selama satu semester atau satu tahun pelajaran dapat terbantu dengan pemanfaatan multimedia, (4) keterampilan yang digunakan sebagai acuan dalam multimedia pembelajaran perlu ditambah, yaitu tidak hanya mencakup keterampilan menyimak, melainkan juga keterampilan berbicara, keterampilan membaca, dan keterampilan menulis (5) mata pelajaran yang digunakan sebagai acuan dalam mengembangkan multimedia pembelajaran tidak hanya mencakup mata pelajaran bahasa Jerman, melainkan juga mata pelajaran lainnya

\section{Daftar Pustaka}

Arikunto, S. (2012). Dasar-dasar evaluasi pendidikan. Jakarta: Bumi Aksara.

Goethe-Institut. (2015). Jerman sebagai bahasa asing di dunia. Retrieved February 19, 2016, from https://www.goethe.de/ins/id/id/s pr/eng/dfw.html.

Heinich, R., Molenda, M., Russell, J., \& Smaldino, S. (1996). Instructional media and technologies for learning.

Englewood Cliffs New Jersey: Prentice-Hall, Inc, Asimon \& Scuster Company.

Januszewski, A., \& Molenda, M. (2008). Educational technology: a definition with commentary. New York: Lawrence Erlbaum Associates.

Mawarni, S., \& Muhtadi, A. (2017). Pengembangan digital book interaktif mata kuliah pengembangan multimedia pembelajaran interaktif untuk mahasiswa teknologi pendidikan. Jurnal Inovasi Teknologi Pendidikan, 4(1), 84. doi:https:// doi.org/10.21831/jitp.v4i1 .10114.

Meltzer, D. E. (2002). The relationship between mathematics preparation and conceptual learning gains in physics: A possible "hidden variable" in diagnostic pretest scores. American Journal of Physics, 70(12), 1259-1268. doi:https:/ / doi.org/10.1119/1.151421 5.

Mukminan. (2004). Desain pembelajaran. Yogyakarta: Program Pascasarjana UNY.

Presiden Republik Indonesia. UndangUndang Republik Indonesia nomor 20 tahun 2003 tentang Sistem Pendidikan Nasional (2003). Indonesia.

Prismanata, Y., \& Ismaniati, C. (2017). Pengembangan multimedia pembelajaran geografi berbasis memory sport pada materi litosfer untuk peserta didik SMA. Jurnal Inovasi Teknologi Pendidikan, 4(1), 97. doi:https:// doi.org/10.21831/jitp.v4i1 .11621 .

Sari, M., \& Apriani, J. (2014). Pengaruh model pembelajaran concept attaiment terhadap hasil belajar siswa kelas viii pada konsep sistem pernapasan (studi eksperimen di smpn 2 gunung sahilan tp. 2013/2014). Bio Lectura, 1(2), 136-144. 
Sudijono, A. (2013). Pengantar evaluasi pendidikan. Jakarta: PT Rajagrafindo Persada.

Widodo, P. (2012). Kompetensi profesional guru bahasa Jerman di Daerah Istimewa Yogyakarta dan Jawa Tengah.

Yogyakarta: Universitas Negeri Yogyakarta. 